\title{
KARST OF SICILY AND ITS CONSERVATION
}

\author{
Cipriano Di Maggio', Giuliana Madonia ${ }^{1}$, Mario Parise $^{2}$, and Marco Vattano
}

\begin{abstract}
In Sicily, karst is well developed and exhibits different types of landscapes due to the wide distribution of soluble rocks in different geological and environmental settings. Karst affects both carbonate rocks, outcropping in the northwest and central sectors of the Apennine chain and in the foreland area, and evaporite rocks, mainly gypsum, that characterize the central and the southern parts of the island. The carbonate and gypsum karsts show a great variety of surface landforms, such as karren, dolines, poljes, blind valleys, and fluvio-karst canyons, as well as cave systems. Karst areas in Sicily represent extraordinary environments for the study of solution forms. In addition, they are of great environmental value because they contain a variety of habitats that hold species of biogeographic significance. Unfortunately, karst areas are increasingly threatened by human activity, mainly in the form of grazing and other agricultural practices, wildfires, quarrying, urbanization, building of rural homes, and infrastructure development. The value of karst features has been recognized by the Sicilian Regional Government since 1981 when it enacted laws to create several nature reserves to preserve the peculiar karst landscapes, including caves. At present, the state of conservation of karst areas in Sicily may be considered to be at an acceptable level, yet numerous issues and difficulties need to be overcome for the effective protection and enhancement of karstlands.
\end{abstract}

\section{INTRODUCTION}

Sicily is the largest island in the Mediterranean Sea with an area of $25,468 \mathrm{~km}^{2}$ and increases to $27,708 \mathrm{~km}^{2}$ when the minor islands are included. About $10 \%\left(2650 \mathrm{~km}^{2}\right)$ of its total land is contained in four Regional Parks and seventy-six Nature Reserves created by the Sicilian Region Government starting in 1981 to conserve geological or landscape features of particular interest; a further five Marine Nature Reserves, covering an area of some $760 \mathrm{~km}^{2}$, were established to conserve marine life and geomorphological aspects (Dimarca, 2004).

Parks and nature reserves preserve areas of scientific importance or outstanding environmental and aesthetic value. Some areas are of geological, paleontological, geomorphological, or archaeological interest; other provide refuge for different species of flora and fauna and are often important staging points and wintering grounds for many migratory birds. Many protected areas are designed specifically to conserve karst features; others include karst landscapes (Table 1).

Karst in Sicily is widespread and exhibits a great variety of surface and underground landforms related to the wide distribution of soluble rocks. About 20\% (more than $6000 \mathrm{~km}^{2}$ ) of the land area consists of carbonates and evaporites, primarily gypsum. Carbonate karst lies mainly in the northwestern and central sectors of the Apennine chain and the foreland area in southeastern Sicily; gypsum karst is chiefly in the central and southern areas of the island, though evaporite landscapes are also present in the northern and western parts of Sicily (Figs. 1 and 8).

The designation of karst landscapes as nature reserves was possible, in part, because of several research studies that highlighted the significance of gypsum and carbonate karst areas.

In addition to the first reports by Marinelli and Gemmellaro dating back to late 1800 s and early 1900 s (Marinelli, 1896, 1911, 1917; Gemmellaro, 1915), gypsum karst was investigated starting in the 1980s. Distribution of gypsum karst areas of Sicily and their geomorphological and speleogenetic features have been described in several articles (P. Madonia et al., 1983; Agnesi et al., 1986; Mannino, 1986; Agnesi and Macaluso, 1989; Biancone et al., 1994; Agnesi et al., 2003). In the last fifteen years detailed studies were carried out on gypsum karren (Macaluso and Sauro, 1996a, 1996b; Macaluso et al., 2001; G. Madonia and Sauro, 2009), genesis of weathering crust and associated forms (Macaluso and Sauro, 1996b, 1998; Ferrarese et al. 2003), natural and anthropogenic sinkholes (Di Maggio et al., 2010), speleogenesis and evolution of karst systems (Panzica La Manna, 1995; Vattano, 2004, 2008, 2010; Buscaglia et al., 2010; G. Madonia and Vattano, 2011), and the role of speleothems in paleoclimate analysis (Calaforra et al., 2008).

Studies on classic karst are less numerous. Some research was performed on the geomorphological setting of the main carbonate-karst areas (Hugonie, 1979; Ruggieri and Grasso, 2000). Many speleological explorations surveyed more than seven hundred caves (P. Madonia et al., 1983; Mannino, 1986; Biancone, 1994; Ruggieri, 2002; Perotti, 1994). This large amount of information prompted studies on the speleogenetic evolution and the

\footnotetext{
${ }^{1}$ Dipartimento di Scienze della Terra e del Mare, University of Palermo, Via Archirafi 20/22 -90123 Palermo, Italy, marco.vattano@unipa.it

${ }^{2}$ CNR IRPI, Via Amendola, 122/I, 70126 Bari, Italy, m.parise@ba.irpi.cnr.it
} 
Table 1. Natural protected karst areas of Sicily (numbers correspond to those on Fig. 8).

\begin{tabular}{|c|c|c|c|c|c|}
\hline No. & $\begin{array}{l}\text { Name of Natural } \\
\text { Protected Area }\end{array}$ & Designation & Karst Heritage & $\begin{array}{l}\text { Surface Area, } \\
\text { ha }\end{array}$ & Management \\
\hline 1 & Grotta di Carburangeli & INR & Carbonate cave & 0.96 & Legambiente \\
\hline 2 & Grotta Conza & INR & Carbonate cave & 12.34 & C.A.I. ${ }^{\mathrm{a}}$ \\
\hline 3 & Capo Gallo & ONR-SCI & Carbonate caves & 585.83 & DRAFD $^{b}$ \\
\hline 4 & Grotta dei Puntali & INR & Carbonate cave & 15.3 & G.R.E. ${ }^{c}$ \\
\hline 5 & Grotta Molara & ONR & Carbonate caves & 40.2 & G.R.E. ${ }^{\mathrm{c}}$ \\
\hline 6 & Serre della Pizzuta & ONR-SCI & Carbonate caves & 414.37 & DRAFD $^{b}$ \\
\hline 7 & $\begin{array}{l}\text { Pizzo Cane, Pizzo Trigna } \\
\text { e Grotta Mazzamuto }\end{array}$ & ONR-SCI & Carbonate cave & 4641.43 & DRAFD $^{b}$ \\
\hline 8 & Serre di Ciminna & ONR-SCI & $\begin{array}{l}\text { Gypsum karst } \\
\text { landscape }\end{array}$ & 310.625 & $\begin{array}{l}\text { Palermo Province } \\
\text { Administration }\end{array}$ \\
\hline 9 & Grotta di Santa Ninfa & INR-SCI & Gypsum cave system & 139.37 & Legambiente \\
\hline 10 & Grotta di Entella & INR-SPA-SCI & Gypsum cave & 19.8 & C.A.I. ${ }^{\mathrm{a}}$ \\
\hline 11 & $\begin{array}{l}\text { Monte San Calogero } \\
\text { (Monte Kronio) }\end{array}$ & INR & $\begin{array}{l}\text { Hypogenic karst } \\
\text { system }\end{array}$ & 52.25 & DRAFD $^{b}$ \\
\hline 12 & Grotta di Sant'Angelo Muxaro & INR & Gypsum cave & 2.25 & Legambiente \\
\hline 13 & Monte Conca & INR-SCI & $\begin{array}{l}\text { Gypsum karst } \\
\text { system }\end{array}$ & 245 & C.A.I. ${ }^{\mathrm{a}}$ \\
\hline 14 & Lago Sfondato & INR & Karst lake & 43.7 & Legambiente \\
\hline 15 & Contrada Scaleri & INR & Gypsum karren field & 11.875 & $\begin{array}{l}\text { Caltanissetta } \\
\text { Province } \\
\text { Administration }\end{array}$ \\
\hline 16 & Lago di Pergusa & SNR-SPA-SCI & Karst lake & 402.5 & $\begin{array}{l}\text { Enna Province } \\
\text { Administration }\end{array}$ \\
\hline 17 & Villasmundo-Alfio system & INR & $\begin{array}{l}\text { Carbonate cave } \\
\text { system }\end{array}$ & 71.66 & Catania university \\
\hline 18 & Grotta Palombara & INR & Carbonate cave & 11.25 & Catania university \\
\hline 19 & Grotta Monello & INR & Carbonate cave & 59.16 & Catania university \\
\hline 20 & $\begin{array}{l}\text { Complesso Immacolatelle } \\
\text { e Micio-Conti }\end{array}$ & INR-SCI & Volcanic caves & 69.9 & Catania university \\
\hline 21 & Zingaro & ONR-SPA-SCI & Carbonate caves & 1600 & DRAFD $^{\mathrm{b}}$ \\
\hline 22 & Monte Pellegrino & ONR-SCI & Carbonate caves & 1016.87 & Rangers d'Italia \\
\hline 23 & Madonie Geopark & Regional Park & $\begin{array}{l}\text { Karst landscapes } \\
\text { and caves }\end{array}$ & 39941 & $\begin{array}{l}\text { Madonie Park } \\
\text { Authority }\end{array}$ \\
\hline 24 & Mount Etna Park & Regional Park & Volcanic caves & 58095 & Etna Park Authority \\
\hline 25 & Lago Preola e Gorghi Tondi & INR-SCI & Karst lakes & 335.62 & W.W.F. ${ }^{\mathrm{d}}$ \\
\hline 26 & Torre Salsa & ONR-SCI & $\begin{array}{l}\text { Gypsum karst } \\
\text { landscape }\end{array}$ & 761.62 & W.W.F. ${ }^{\mathrm{d}}$ \\
\hline 27 & Lago Soprano & ONR-SCI & Karst lake & 59.79 & $\begin{array}{l}\text { Caltanissetta } \\
\text { Province } \\
\text { Amininstration }\end{array}$ \\
\hline 28 & $\begin{array}{l}\text { Pantalica, Valle dell'Anapo } \\
\text { e T. Cavagrande }\end{array}$ & ONR & Fluvio-karst canyon & 3712.07 & DRAFD $^{\mathrm{b}}$ \\
\hline 29 & Cavagrande del Cassibile & ONR-SCI & Fluvio-karst canyon & 1059.62 & DRAFD $^{b}$ \\
\hline
\end{tabular}

a Italian Alpine Club.

${ }^{\mathrm{b}}$ Regional Forest Department.

${ }^{\mathrm{c}}$ Ecological Research Groups.

${ }^{\mathrm{d}}$ World Wildlife Fund.

Note: $I N R=$ Integral Nature Reserve, $\mathrm{ONR}=$ Oriented Nature Reserve, $\mathrm{SNR}=$ Special Nature Reserve, $\mathrm{SCI}=$ Sites of Community Importance, $\mathrm{SPA}=$ Special Protection Areas .

physical deposits in selected caves (Messana, 1994; Aricò and Vattano, 2007; G. Madonia and Vattano, 2010), as well as paleoenvironmental and paleoclimatic reconstructions through speleothem analysis (Frisia et al., 2006).
Macaluso et al. (1994) focused their attention on the safeguarding and sustainable use of karst geo-ecosystems.

All these studies highlighted the importance of gypsum and carbonate karst in many areas of Sicily as extraordi- 


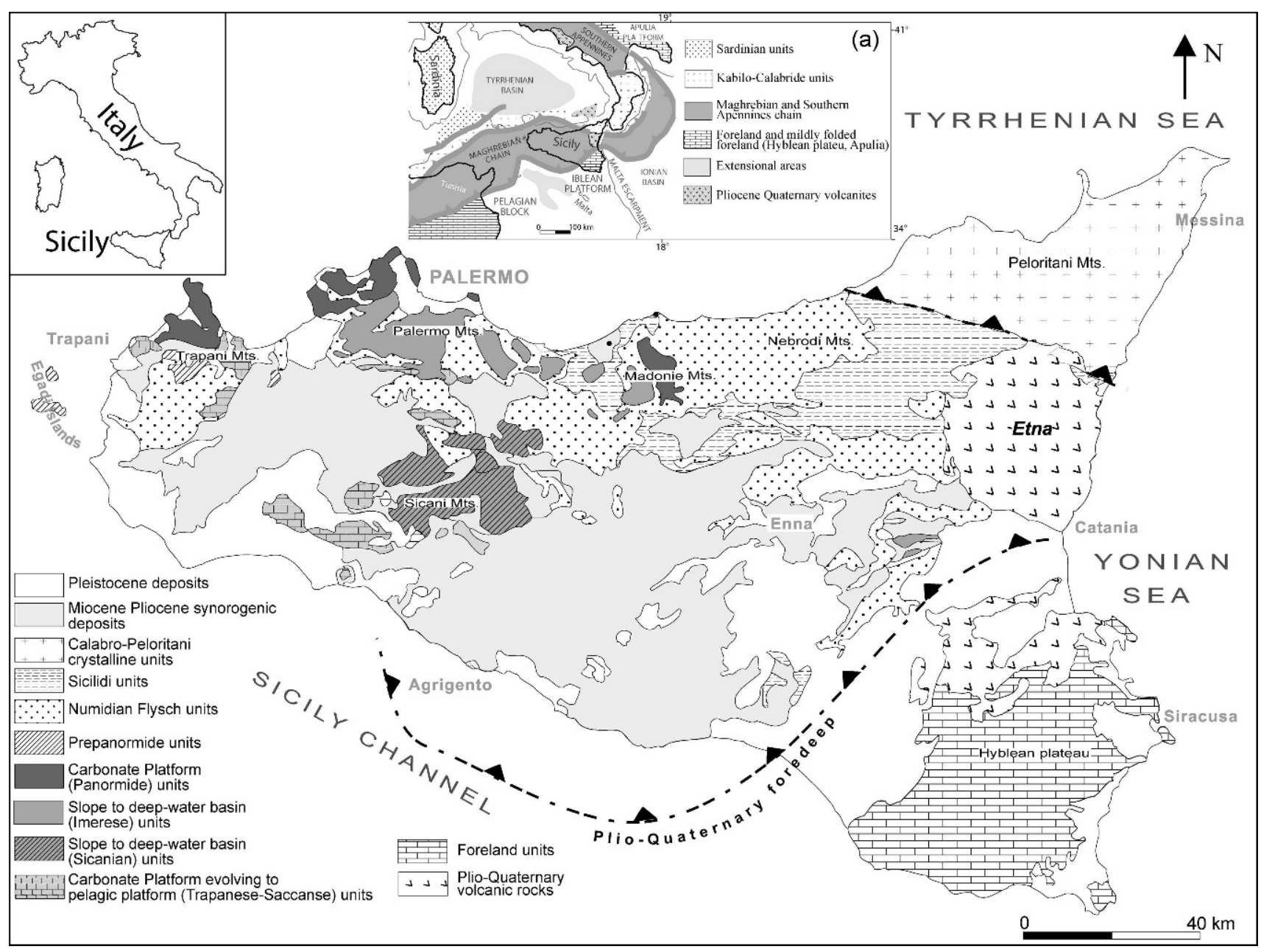

Figure 1. Structural map of Sicily (modified after Catalano et al., 1996, and Avellone et al., 2010). The inset (a) shows the tectonic map of the central Mediterranean area (after Catalano et al., 2000).

nary environments of diverse and peculiar landscapes for the study of solution forms. Nevertheless, these areas are subject to human activity. The main pressures on karst result from grazing and other agricultural practices, wildfires, quarrying, urbanization, building of rural homes, and infrastructure developments such as road and waste dumps. To preserve the peculiar surface landforms and caves, the Sicilian Regional Government designated some karst areas as nature reserves.

The goal of this paper is to illustrate the main features of the karst landscapes in Sicily in different geological and lithological settings and to describe the main conservation measures adopted for their protection.

\section{Geological Setting of Sicily}

Sicily is a segment of the Alpine collisional belt along the Africa-Europe plate boundary that links the African Maghrebides to the west and southwest with the Calabria and the Appennines to the east and northeast (Catalano et al., 1996, 2000; Avellone et al., 2010; Fig. 1). The geological setting of Sicily is characterized by three main structural elements: a foreland Hyblean Plateau located in southeastern Sicily, made up of Triassic-Liassic platform and scarp-basin carbonates overlain by Jurassic-Eocene pelagic carbonates and Tertiary open-shelf clastic deposits; a northwest-dipping foredeep located north of the foreland, consisting of Plio-Pleistocene pelagic marly limestones, silty mudstones, and sandy clays overlying Messinian evaporites; and a complex chain composed of several embricate units geometrically arranged in a thrust pile verging toward the east and the southeast, including the Calabro-Peloritani Units, located in northeastern Sicily, formed of Hercynian crystalline units with a Mesozoic terrigenous cover and Plio-Pleistocene clastic and pelagic sediments and the Sicilian Maghrebian Units consisting of Meso-Cenozoic siliceous rocks, basin pelagic turbiditic carbonates, and platform and pelagic carbonates. These units are tectonically overlain by a roof thrust formed of Oligo-Miocene turbiditic successions, or Lower-Middle Miocene glauconitic calcarenites and pelagic mudstones, or Lower-Pleistocene foreland or satellite basin deposits, 
deformed and detached from the substratum (Catalano et al., 1996, 2000). The Maghrebian Units crop out along the northern Sicily belt in the Madonie, Palermo, and Trapani Mountains and in the western and southwestern sectors of the island. Southern and central Sicily are characterized by the presence of Cretaceous-Lower Pleistocene clasticterrigenous deposits and Messinian evaporites.

\section{Karst in CARbonate Rocks}

Karst in the carbonate rocks of Sicily occurs mainly in the Meso-Cenozoic platform limestones and, subordinately, the Mesozoic slope to basin dolomitic limestones with intercalations of marls and siliceous rocks.

The main and best-developed karst forms are in the northwestern Apennine chain (Trapani, northern Palermo, and eastern Madonie Mountains), where large platform limestone bodies, several hundred meters thick, crop out. To the northeast and south of the chain, karst forms are fewer and less significant, due to less extent and thickness of platform limestones in the Nebrodi, Peloritani, southern Palermo, and northern and southern Sicani Mountains, and to lower solubility of slope to basin dolomitic limestones in the central Trapani, central-southern Palermo, central Sicani, and western Madonie Mountains. In the Hyblean Plateau foreland, deep fluviokarst canyons formed as a consequence of the Quaternary uplift, while horizontal caves are due to the presence of thin horizontal intercalations of limestones between the marl and siliceous levels (Figs. 1 and 8).

Areas marked by thick and extensive platform limestones show a great variety of surface karst forms, ranging from small (karren) to large (dolines, poljes, valleys, and karst planation surfaces), as well as cave systems.

Karren are very widespread, with different typologies according to lithology, topographic setting, structural conditions, presence of soil, and micro-climatic and other geographic factors (Figs. 2a, 2c). Furthermore, large areas made up of densely fractured rock may be characterized by ruiniform reliefs with 0.5 to $3 \mathrm{~m}$ high angular pinnacles, and there are rare rock cities made up of remnant blocks and knobs of rock, separated by more or less linear corridors.

Solution dolines are less numerous in the Trapani (a few tens) and Palermo (fewer than a hundred) Mountains, while they are numerous (several hundreds) in the Madonie Mountains, mainly due to the presence of a wide summit tableland, made up of planation surfaces, in the Carbonara Massif area (Fig. 3a). On the large planation surfaces, the larger depressions (up to 400 to $900 \mathrm{~m}$ in diameter) are elongated due to the presences of joints, fractures, or faults, and often originated by the coalescence of two or more dolines. Smaller depressions (diameters between 10 and $400 \mathrm{~m}$ ) have a sub-circular perimeter if located on flat planation or horizontal structural surfaces, while they show an elongated contour if sited at the bottom of dry valleys (Fig. 3c), along structural discontinuities, or on slopes. In the first two cases it is also possible to observe alignments of closed dolines, while in the last case, the dolines are generally open and single.

Four poljes, with steep sides and flat bottoms, have been recognized. They have maximum widths between 2 and $5 \mathrm{~km}$, cover areas of 3 to $8 \mathrm{~km}^{2}$, and present relief of some hundreds of meters. Poljes are present in the Trapani (Purgatorio polje), Palermo (Falconeri polje, Piano San Nicolò polje), and Madonie (Piano Battaglia polje, Fig. 3b) Mountains. These large depressions are sited in complex tectonic depressions due to E-W (Purgatorio polje), ENEWSW and NNW-SSE (Falconeri polje), E-W and NE-SW (Piano San Nicolò polje), and ENE-WSW and NW-SE (Piano Battaglia polje) extensional or reverse/strike-slip faults, as evidenced by geological (anomalous contacts among litostratigraphic units, kinematic indicators along fault planes) and geomorphological (faults or fault-line scarps) data. Generally, the faults have a passive role in the development of poljes. Their genesis seems to be influenced mainly by selective erosion of clays at the bottom of the poljes stratigraphically or tectonically interposed between the limestone rocks that form the steep slopes identified as fault-line scarps or inclined structural surfaces. The presence of two fault scarps, ten of meters high, along the north-northwest and east-northeast margins of the Piano Battaglia polje suggests an active tectonic control in the development of this depression (Fig. 3b).

In the platform carbonates of Sicily, the fluviokarst valleys are dry valleys and canyons, with maximum lengths of 1 to $3 \mathrm{~km}$. Dry valleys are mainly located in the Palermo and Madonie Mountains; canyons also may be found in the Trapani Mountains. Dry valleys are often set along structural lines. In particular, in the Carbonara Massif area they seem to be controlled by the northwest-southeast and northeast-southwest fault systems (Fig. 3c). In consequence of lowering of the karst base level, these valleys have been abandoned and now are seen as hanging valleys.

Planation surfaces are present in small patches at various heights between 200 and $1950 \mathrm{~m}$ a.s.l., both at the tops of ridges and along slopes. They are often karstified and well preserved in areas made up of carbonate bedrock. Generally, their genesis seems to be linked to several stillstand phases of the general base-level erosion. In some cases, their origin is due to marginal corrosion that affected the footslopes along the polje bottom during flood events. Subsequent relief inversion owing to dismantling of the margins is the cause of the current arrangement of the karst planation surfaces located in summit areas or along the mountainsides. Finally, several hundred horizontal and vertical caves are indicative of a well-developed deep karst network (Fig. 4b and 4d).

In the platform limestones outcropping in the Madonie Mountains, the best developed caves are the Abisso del Gatto and the Abisso del Vento (Biancone, 1994; Macaluso et al., 1994). The first is actually the deepest cave of Sicily, 


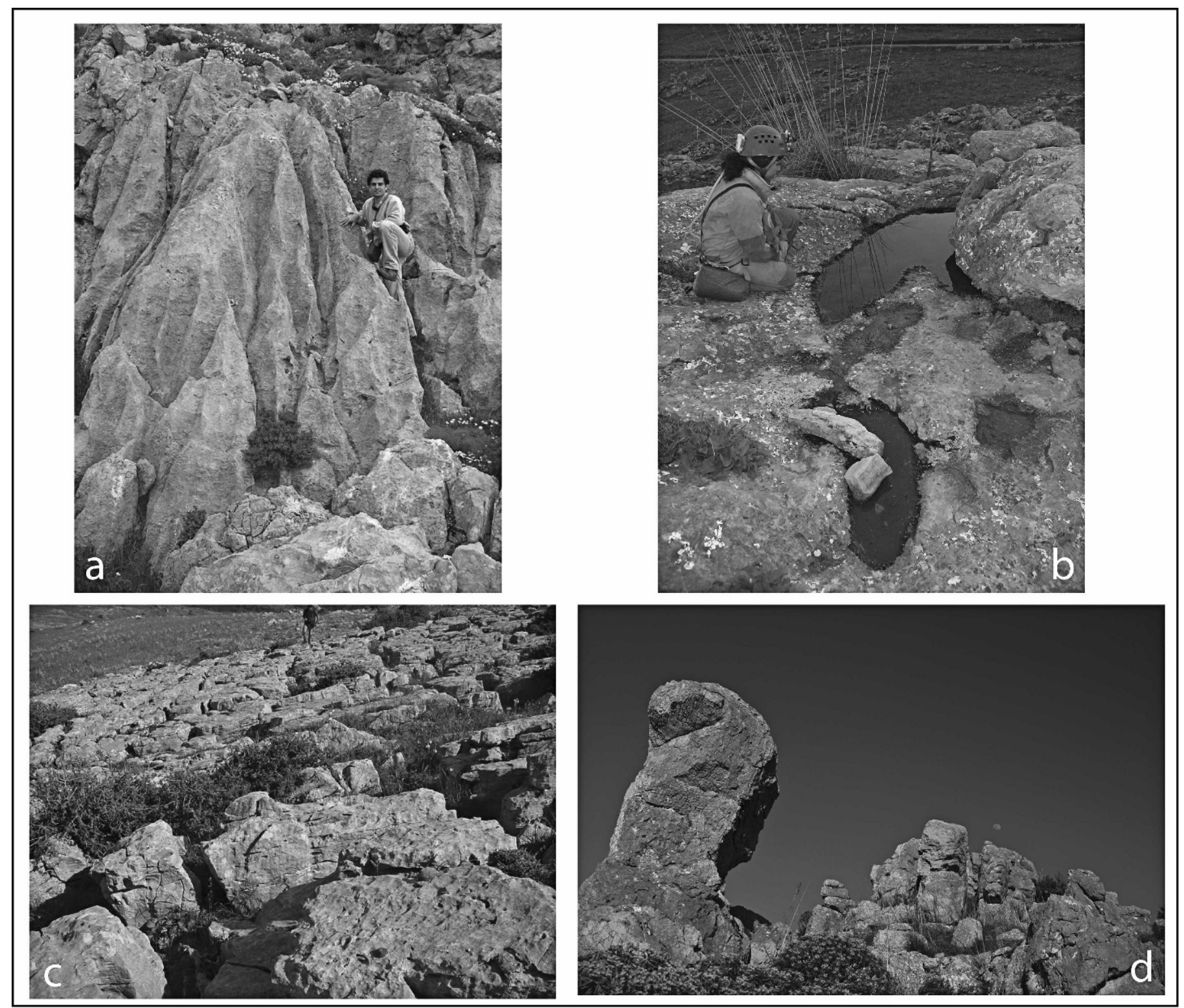

Figure 2. a. Runnels in platform limestones (Madonie Mountains; photo V. Culotta). b. Large solution pans in slope to basin dolomitic limestones (Palermo Mountains). c. Limestone pavement with rectangular patterns of clints and grikes (Madonie Mountains; photo V. Culotta). d. Ruiniform relief in slope to basin dolomitic limestones (Palermo Mountains).

reaching $320 \mathrm{~m}$ of depth. It is a temporary sink cave, with narrow and meandering galleries connected by a sequence of shafts (Fig. 4b), and its sink entrance absorbs waters flowing only during prolonged rainfall. The Abisso del Vento, $220 \mathrm{~m}$ deep and about $2 \mathrm{~km}$ long, consists of several superimposed tiers of galleries and big rooms joined by vertical shafts and is strongly controlled by tectonics. This cave is characterized by terra rossa deposits rich in hematite, siderite, and goethite and the presence of a large variety of carbonate speleothems (Aricò and Vattano, 2007).

The Trapani Mountains are characterized by a large number of caves with a mainly vertical trend. The deepest cavities, located in the Purgatorio polje area, are the
Abisso Purgatorio, $194 \mathrm{~m}$ deep, and the Abisso delle Gole, $120 \mathrm{~m}$ deep (Ruggieri, 2002). In the eastern sector of the Trapani Mountains and in the platform carbonates of southwestern Sicily, some well-developed, deep hypogenic caves linked to thermal groundwater, such as Grotta dell'Eremita, Abisso dei Cocci (Fig. 4a), and the cave complex of Kronio Mountain, occur (Messana, 1994; Perotti, 1994).

Areas characterized both by small surfaces of platform limestones (southern Palermo, Sicani, Nebrodi, and Peloritani Mountains) and by slope to basin dolomitic limestones (central-southern Palermo, central Trapani, and western Madonie Mountains) show less development of karst. 

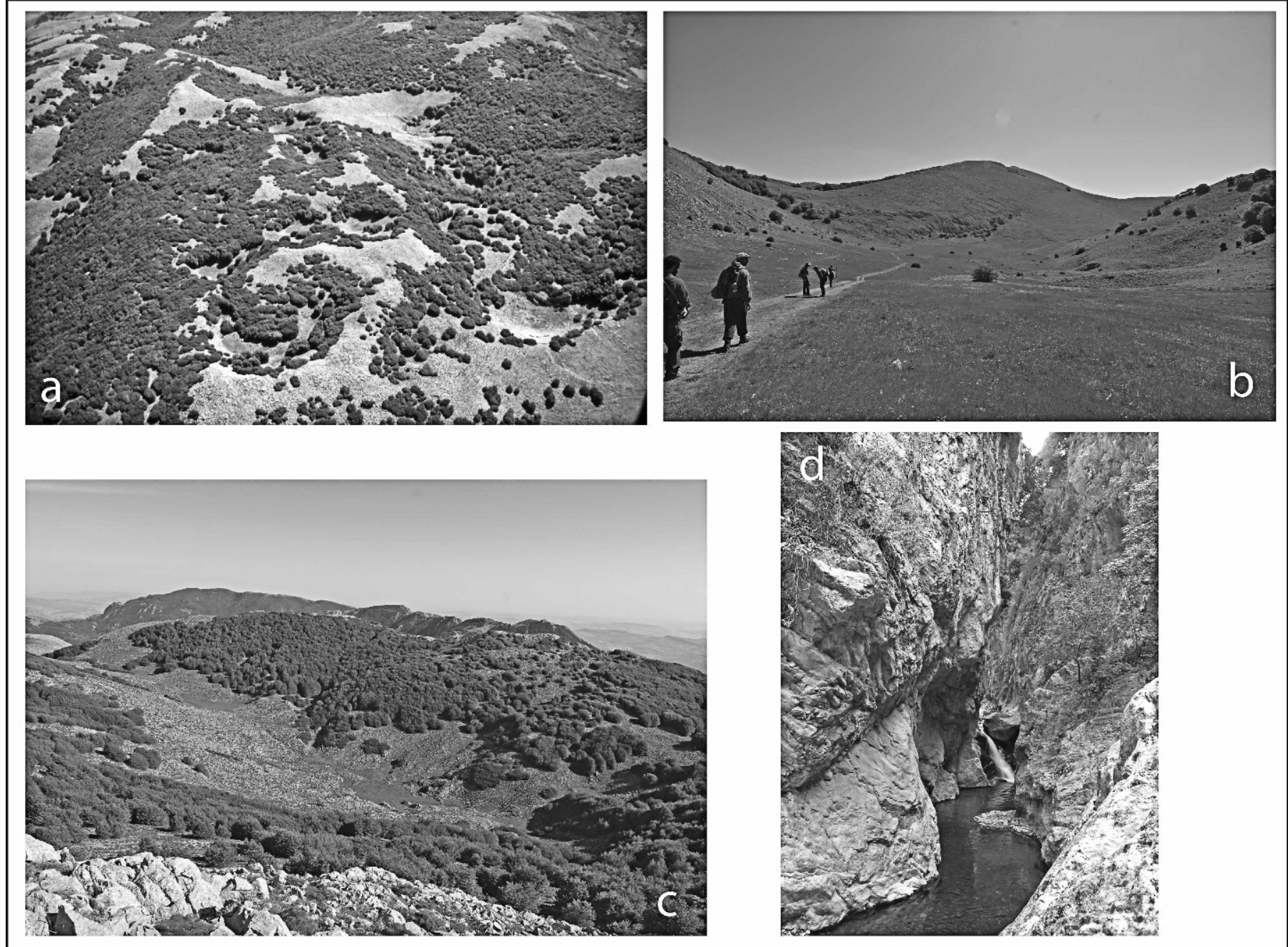

Figure 3. a. Doline alignment following major tectonic lineaments, in the summit area of Carbonara Massif (Madonie Mountains); b. The Piano Battaglia polje (Madonie Mountains). c. Dry valley on the highest reaches of Carbonara Massif; at the bottom alignments of dolines are recognizable (Madonie Mountains). d. Fluvio-karst canyon cut in dolomitic limestones (Nebrodi Mountains).

Platform limestones are marked by a great variety of karren, a few tens of dolines, and some short superimposed canyons. Dolines are generally elongated along E-W, WNW-ESE, NE-SW, and NW-SE fault lines; they exhibit maximum diameters ranging from 10 to $150 \mathrm{~m}$ and minimum diameters between 1 and $30 \mathrm{~m}$. Canyons generally are from 400 to $800 \mathrm{~m}$ long and between 70 and $100 \mathrm{~m}$ wide and may reach up to $100 \mathrm{~m}$ in depth (Fig. 3d).

In dolomitic limestones, the main karst landforms are the Pianetto polje and the Piano della Stoppa polje in the Palermo Mountains, with maximum width of 4 to $6 \mathrm{~km}$ and located along grabens bounded by NNE-SSW (Pianetto polje) or E-W and NW-SE (Piano della Stoppa polje) fault slopes and systems of hanging dry valleys in Monte Speziale in the Trapani Mountains and Monte dei Cervi in the Madonie Mountains. These valleys, between 1 and $3 \mathrm{~km}$ long, host elongated dolines developed along depressions due to rock spreading or tectonic depressions controlled by NNW-SSE (Monte Speziale) or E-W, NESW, and N-S (Monte dei Cervi) faults.

In addition, it is possible to distinguish large elongated and sub-circular dolines with maximum diameters ranging from 200 to $700 \mathrm{~m}$, dozens of smaller dolines with diameters between 1 and $100 \mathrm{~m}$, dozens of short fluviokarst canyons a hundred meters long and deep set along faults or maximum-slope lines, and rare karren fields mainly made up of ruiniform reliefs (Figs. 2b, 2d).

The cave systems are not very developed. There are only some tens of cavities, with horizontal and/or vertical development strictly influenced by tectonic features. They are generally controlled by faults and characterized by narrow passages, deep shafts, breakdown rooms, and an abundance of carbonate speleothems (G. Madonia and Vattano, 2010; Fig. 4c). 

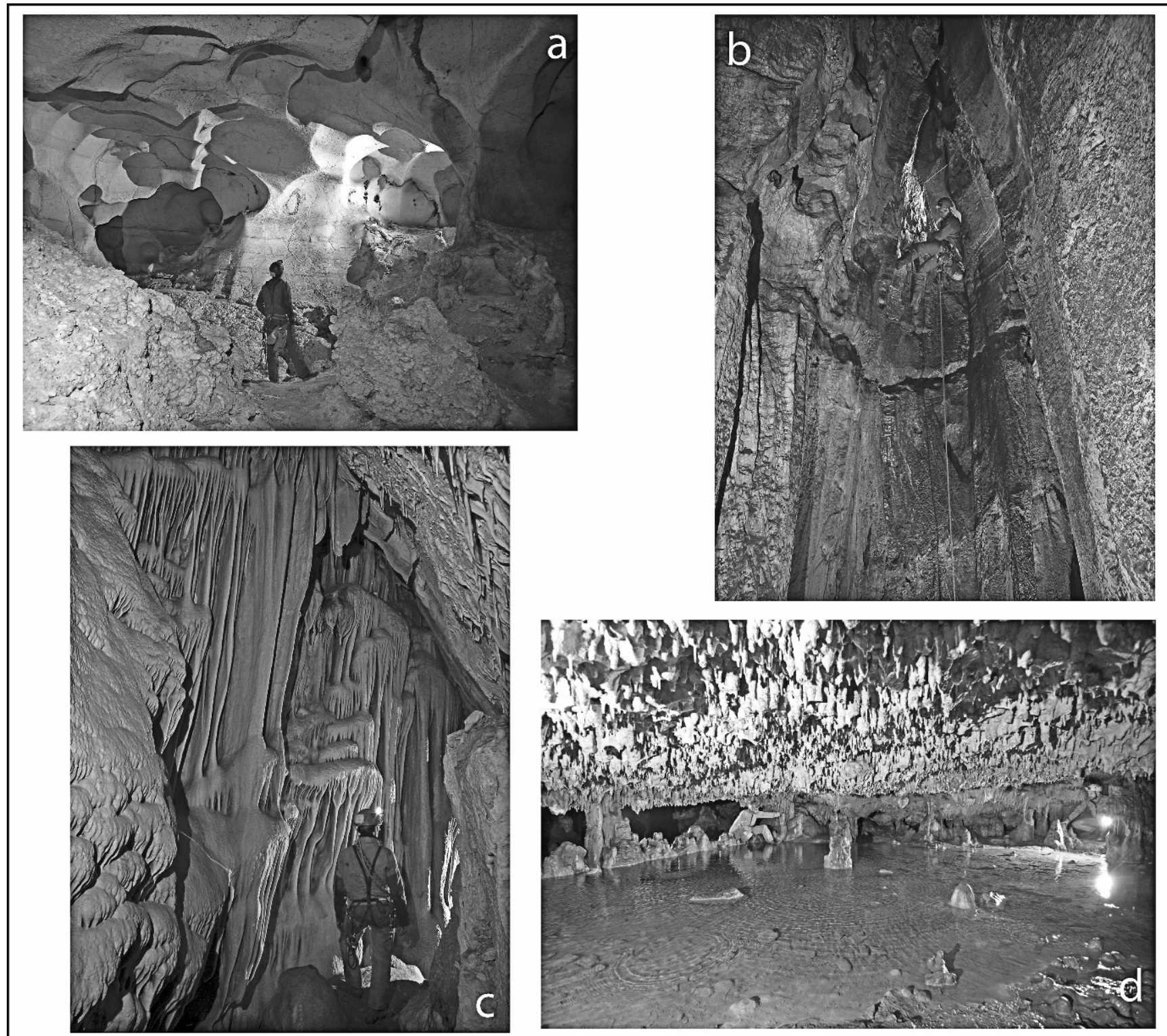

Figure 4. a. Abisso dei Cocci (Trapani Mountains), hypogenic sub-horizontal passage with cupolas in the ceiling. b. Abisso del Gatto (Madonie Mountains), 19m deep shaft connecting two tiers of galleries. c. Pozzo Fiandra (Palermo Mountain), faultguided passage with large carbonate speleothems on the walls. d. Grotta di Carburangeli Nature Reserve (Palermo Mountain), a small pool in the main passage of the cave, rich in carbonatic speleothems.

The Hyblean Plateau, where platform and basin limestones crop out, is characterized by long and deep fluviokarst canyons that strike along the main regional gradients. The streams flow from the top of the plateau and develop in northwest-southeast and southwest-northeast (toward the Ionian Sea) or northeast-southwest (toward the Sicily Channel) directions. In particular, they are superimposed streams formed after lowering of the general base level as a consequence of uplift of the area. Genesis of these canyons is mainly due to fluvial downcutting. Karst dissolution is considered to be less important because of the widespread occurrence of impure limestones containing a siliceous component and alternating with marl and clay layers. In fact, other large or small surface karst forms are almost absent or not well developed. Due to the presence of only thin horizontal layers of limestone between marl and siliceous levels, caves in this sector have a predominantly horizontal development.

On the whole, both structurally controlled karst forms (fluviokarst valleys, dolines, shafts, ruiniform relief, and rock cities developed along structural lines, as well as poljes developed in depressions produced by tectonics or selective erosion) and karst forms not controlled by structure (karst planation surfaces, superimposed canyons on the Hyblean 
Plateau, and some dolines mainly sited along slopes) occur in carbonate rocks of Sicily. Furthermore, the larger forms can be classified as karstified tectonic depressions, depressions controlled by selective erosion where clays are intercalated between carbonate rocks, karst valleys or elongated depressions developed along faults or fractures, depressions developed in areas with strongly fractured rocks, and karst planation surfaces and small depressions that cut structures.

Finally, two different karst processes can be recognized, the first linked to phases of stillstand of the karst base level that produced horizontally developed forms (e.g., karst planation surfaces, horizontal caves, and depressions with breadth more developed than depth), and the second to lowering of the base level, which created deeply developed forms (e.g., fluviokarst canyons, pits, and deep depressions).

\section{Karst In Gypsum Rocks}

In Sicily, the gypsum karst is well developed and shows different kinds of surface and subsurface landforms with over $1000 \mathrm{~km}^{2}$ of Messinian evaporites, outcropping mainly in southern and central Sicily. Additional small gypsum outcrops occur in the northern and western parts of the island. Evaporites are composed of a succession of evaporitic limestone, gypsum, and salt, with many intercalations of clays, marls, and carbonates (Decima and Wezel, 1971; Catalano, 1986). The gypsum units are made of branching selenite, banded selenite, massive selenite, and detrital gypsum, arranged in centimeter to meter thick beds separated by thin marl and carbonate layers. Thick, massive evaporitic carbonates are, in some places, intercalated between the gypsum beds. The gypsum units lie on clay, marly-clayey, and sandy-clayey formations of the Lower Messinian-Middle Serravallian, and are overlain locally by Pliocene calcarenites and marly clays or Pleistocene clays and arenites. The evaporitic successions were generally affected by the Plio-Pleistocene tectonic phases that generated south-trending fold-and-thrust belts and high-angle faults that produced lateral contacts between the Messinian gypsum units and the older marlyclayey deposits.

Several types of landscape characterize the gypsum karst of Sicily. From the morpho-structural standpoint, the most common styles are tabular plateaus, homoclinal ridges, fault scarps, folded relief, and isolated large gypsum blocks floating on clays. In addition, slope, fluvial, lacustrine, coastal, and hypogean geo-ecosystems can be distinguished (Sauro, 2003a; G. Madonia and Sauro, 2009).

Transitions between fluvial and karst processes are evident in many gypsum areas (Marinelli, 1917; Agnesi and Macaluso, 1989). These are the consequences of contact karst, due to a vertical transition from impervious rocks to soluble rocks, a lateral tectonic contact between soluble and insoluble rocks, or thin, discontinuous clastic covers of different permeability intercalated with the gypsum outcrops. The coexistence of fluvial and karst forms exemplifies the progressive transition from a surface hydrographic network to an underground circulation (Forti and Sauro, 1996). The surface karst landforms exhibit a large variety of types ranging from micro (karren) to very large (polje).

Gypsum and small salt outcrops, with solubilities respectively of 2.5 and $360 \mathrm{~g} \mathrm{~L}^{-1}$ (Klimchouk, 1996; Ford and Williams, 2007), are characterized by several types of karren. The karren are widespread and show a variety of shapes due to the large extent of the outcrops, the different lithofacies, and the climate. Karren features are commonly present in all kinds of evaporites, macrocrystalline selenitic gypsum, detrital gypsum with various grain sizes, microcrystalline gypsum (Figs. 5a, 5b), and salts such as halite and kainite. Both the origin and evolution of karren are controlled by several processes such as solution and recrystallization, granular disintegration, carbonation, and phenomena linked to biological activity (Macaluso and Sauro, 1996a, 1996b; Macaluso et al., 2001; G. Madonia and Sauro, 2009). The karren features vary from nano- and micro-forms to very large forms and develop both on the exposed surfaces and under permeable covers. Karren are present on extensive outcrops, such as denuded slopes and hilly summits, and even on the exposed faces of little stones and isolated blocks. Particular environments where some specific types of karren have been recognized are the fluvial and coastal geo-ecosystems (Fig. 5c) and some artificial and semi-artificial geo-ecosystems, such as quarries, mine tailings, and dry walls. Generally, similarities can be seen between the gypsum and limestone karren in Sicily, despite important differences (G. Madonia and Sauro, 2009).

On bare gypsum surfaces gypsum bubbles (tumuli) are widely diffused (Macaluso and Sauro, 1998; Calaforra and Pulido-Bosch, 1999). These are dome-like bulges made up of a thin layer of rock, ranging in thickness between a few centimeters and some decimeters, enclosing an underlying void. Gypsum bubbles develop mainly on selenitic gypsum and show diameters between 1 and 6 or 7 meters (Fig. 5d; Macaluso and Sauro 1996b, 1998; Ferrarese et al., 2003).

Among the medium and large landforms, dolines are the best-developed forms in Sicilian gypsum-karst areas, both in number and typology, though blind valleys and poljes occur as well. The dolines have shapes that vary from regular conical, truncated-conical, or hemispherical to irregular and asymmetrical (Fig. 6a). The latter are generally elongated according to the slope and show a significant difference between maximum and minimum depth; sometime these indicate the transition to blind valleys. Complex forms deriving from the merging of simpler features occur as well. Dolines vary from a few meters to several hundreds of meters in average diameter and from a few decimeters to tens of meters in depths. 


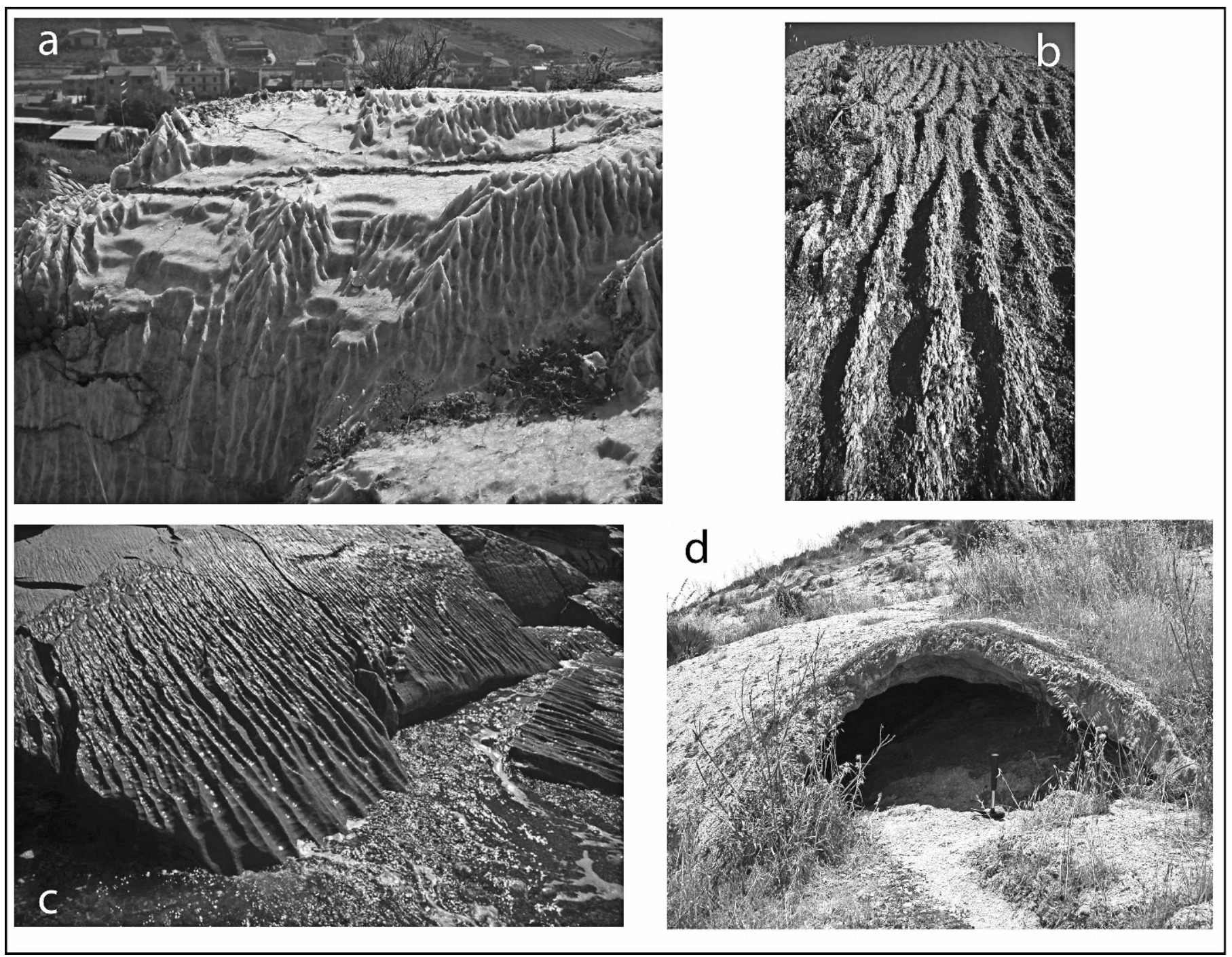

Figure 5. a. Karren in microcrystalline gypsum (southern Sicily). b. Solution runnels on steep slope of macro-crystalline selenitic gypsum (Grotta di Santa Ninfa Nature Reserve). c. Coastal solution runnels and scallops in pelitic gypsum due to wave splashing and surf erosion (southern Sicily). d. Gypsum bubble in macro-crystalline gypsum (southern Sicily).

The dolines are caused by normal solution (mainly point recharge), collapse, suffosion, or subsidence (Sauro, 2003b; Ford and Williams, 2007). In some areas of Sicily, chains of aligned point-recharge dolines, formed as a consequence of an upstream migration of the swallets of small blind valleys, follow the pattern of old fluvial networks that developed on the impermeable cover. Dolines often are grouped in a well-defined karst unit, where they occupy the entire karstifiable area to form a honeycomb karst type, as in the Grotta di Santa Ninfa and Serre di Ciminna nature reserves (Fig. 8; Agnesi and Macaluso, 1989; Sauro, 1996, 2005).

Where gypsum is covered by pervious but not soluble rock, several karst lakes have formed in small subsidence dolines, as in the Lago Preola and Gorghi Tondi, Lago di Pergusa, and Lago Soprano nature reserves (Figs. 6d, 8). These lakes change rapidly in dimensions, depth, and shape due to subsidence, and erosion, and changes in rainfall (Di Maggio et al., 2010).

In southern Sicily, some kilometer-long polje-like depressions linked to folded relief are recognizable, among which the most developed is the Pantano, near Agrigento (Fig. 6c). This polje consists of a flat and nearly horizontal floor $2.5 \mathrm{~km}$ long and $900 \mathrm{~m}$ wide, bounded by steep slopes, and formed in a tectonic depression linked to a northwest-southeast thrust.

The karst valleys are generally blind valleys that may be entirely cut in gypsum, often assuming a gorge shape, or they may be cut in insoluble sediments and end blindly at a gypsum threshold. Sometimes they have their upstream part on insoluble rocks and the downstream end incised in the gypsum (Fig. 6b; Macaluso et al., 2003).

In Sicily, over two hundred gypsum solution caves are known. Generally, they open at the end of a blind valley

Journal of Cave and Karst Studies, August 2012•165 

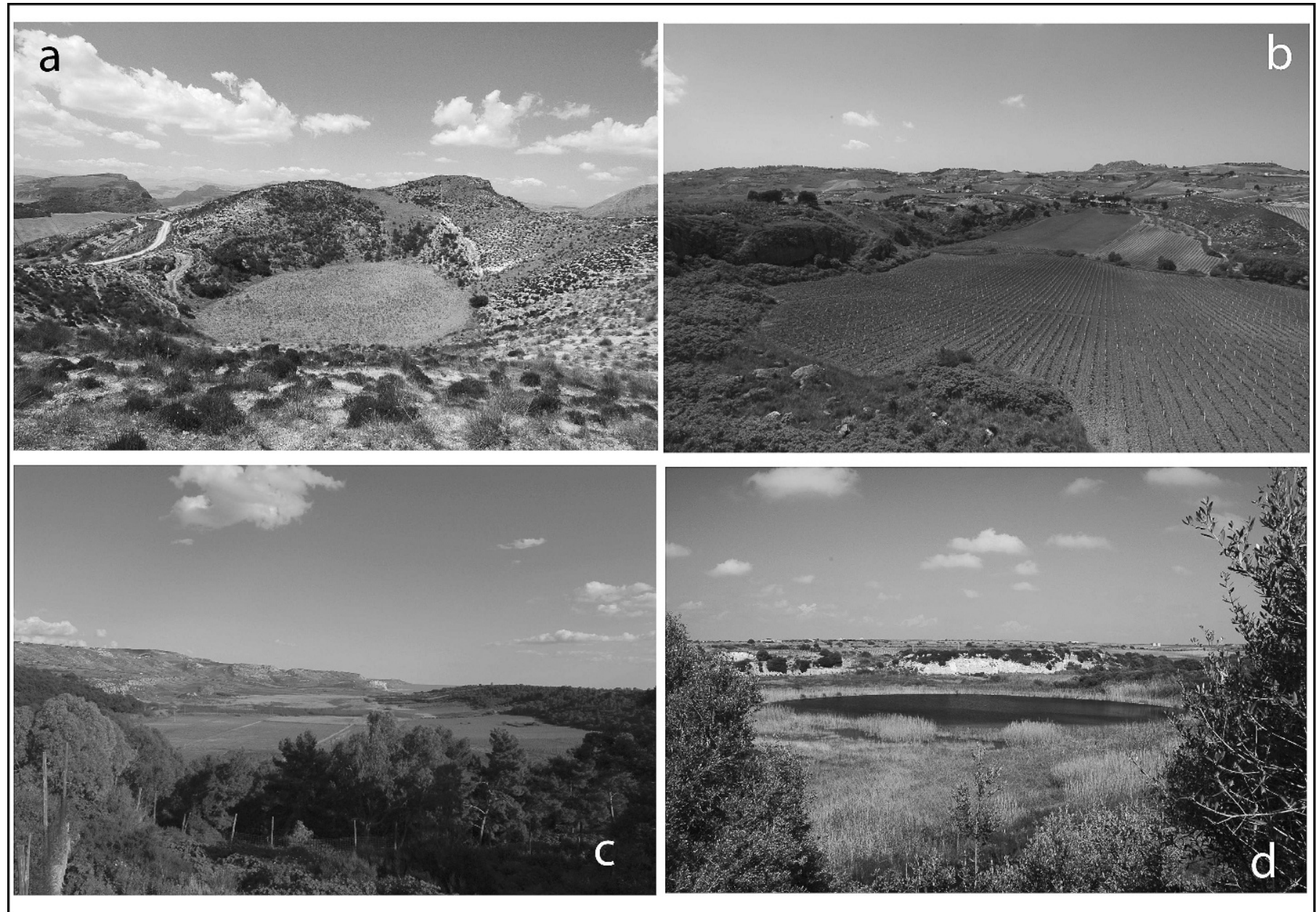

Figure 6. a. Example of truncated-conical solutional drawdown doline in gypsum karst (northern Sicily). b. Blind valley feeding the Grotta di Santa Ninfa gypsum cave; this valley has the upstream part in insoluble rocks and the downstream side incised in gypsum (Grotta di Santa Ninfa Nature Reserve). c. The Pantano, a polje formed at a tectonic depression linked to a northwest-southeast oriented thrust (Torre Salsa Nature Reserve). d. Subsidence doline developed in Pleistocene calcarenites overlying gypsum rocks and hosting a small karst lake (Lago Preola e Gorghi Tondi Nature Reserve).

or at sink points located at doline bottoms. Gypsum caves in Sicily reflect the features of classic gypsum karst systems under unconfined conditions, consisting of a main drainage tube, characterized by rapid flowing water, with generally inactive tributaries locally filled by alluvial or breakdown deposits (Forti and Sauro 1996; Forti and Rossi, 2003). Usually the caves are composed of lowgradient galleries at different elevations connected by shafts related to stillstands and lowering of the local base level (Figs. 7a, 7c, 7d; Vattano, 2004, 2008; G. Madonia and Vattano, 2011).

Solution caves have several different relations to surface hydrology: through-caves, sink caves (e.g., Inghiottitoio di Monte Conca and Inghiottitoio di Sant'Angelo Muxaro), spring caves (Risorgenza di Monte Conca), active caves with streams flowing underground but with no explorable connection to either sink or spring system (Grotta di Santa Ninfa), and finally relict, inactive caves (Grotta di Entella and Inghiottitoio delle Serre) (Forti and Sauro, 1996). Actually, the longest and deepest cave in the Sicilian gypsum is the Monte Conca system that is composed of a sink cave, an active resurgence, and a relict one, reaching more than $2.3 \mathrm{~km}$ in length and $132 \mathrm{~m}$ in depth (Vattano, 2004, 2008; G. Madonia and Vattano, 2011).

Many caves show large amounts of physical and chemical filling. The first consists of well-stratified alluvial sediments of various grain size (gravel, sand, clay, and silt) and breakdown materials. Chemical deposits are mainly gypsum and carbonate speleothems, plus secondary minerals such as sulfur, opal, phosphates, oxides, and metallic minerals (Hill and Forti, 1997). Gypsum speleothems over carbonate ones occur in many gypsum cavities (Fig. 7b); this alternation can be a powerful instrument in paleoclimate studies, as demonstrated by Calaforra et al. (2008) using samples from the Grotta di Entella. 


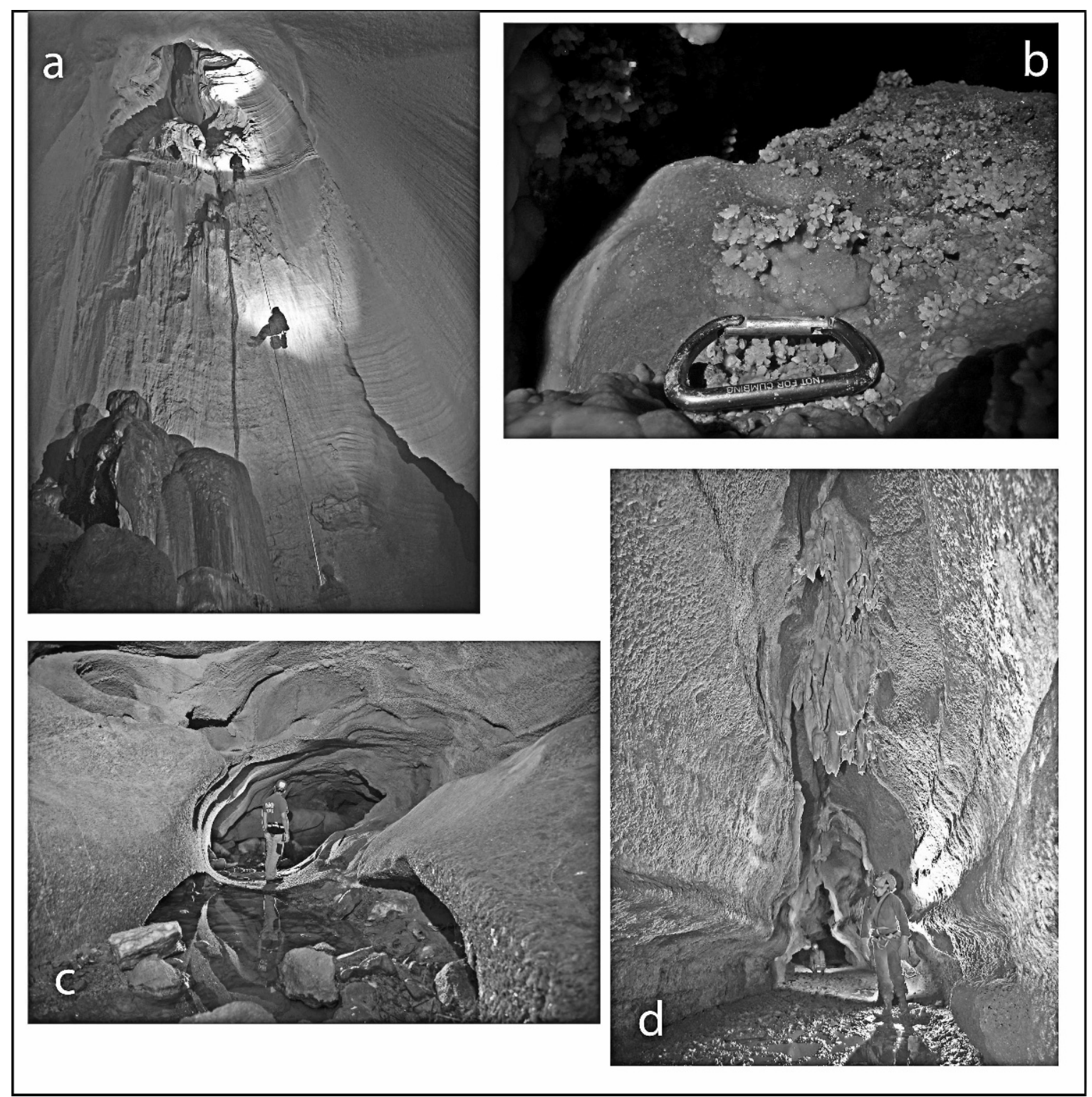

Figure 7. a. Waterfall shaft $26 \mathrm{~m}$ deep in the Inghiottitoio di Monte Conca; carbonate flowstones cover breakdown blocks at the bottom and the wall where water flows (Monte Conca Nature Reserve). b. Gypsum crystals on carbonate speleothems (Grotta di Santa Ninfa Nature Reserve). c. A horizontal passage with elliptical section linked to overflow episodes in the Vallone Ponte gypsum karst system (central Sicily). d. Subhorizontal gallery in gypsum cave; on the walls, notches due to selective solution are recognizable, and massive carbonate speleothems grow from the roof (Grotta di Santa Ninfa Nature Reserve).

\section{Protected Karst Areas in Sicily}

Since 1981, the Sicilian Regional Government has enacted several laws for the creation of parks and nature reserves to preserve areas of scientific importance or outstanding environmental beauty. The most important steps were the "Norms for the establishment of parks and nature reserves in Sicily" (Regional Laws No. 98/1981 and No. 14/1988), approval of the "Parks and Nature Reserves Regional plan" (Regional Decree No. 970/1991), and the establishment of parks and nature reserves and assignment of management of the protected areas (several regional decrees between 1984 and 2008; Dimarca, 2004). Although there is no specific legislation for the protection of karst landscapes, as many as nineteen of the nature reserves were established for the conservation of karst features because of their intrinsic value (Fig. 8, Table 1). Of these, twelve reserves provide for the protection of gypsum or carbonate caves. Some caves are of great speleological, geological, and hydrological interest, and others contain important paleontological remains. In addition, many of these caves are of biological interest for the presence of significant 


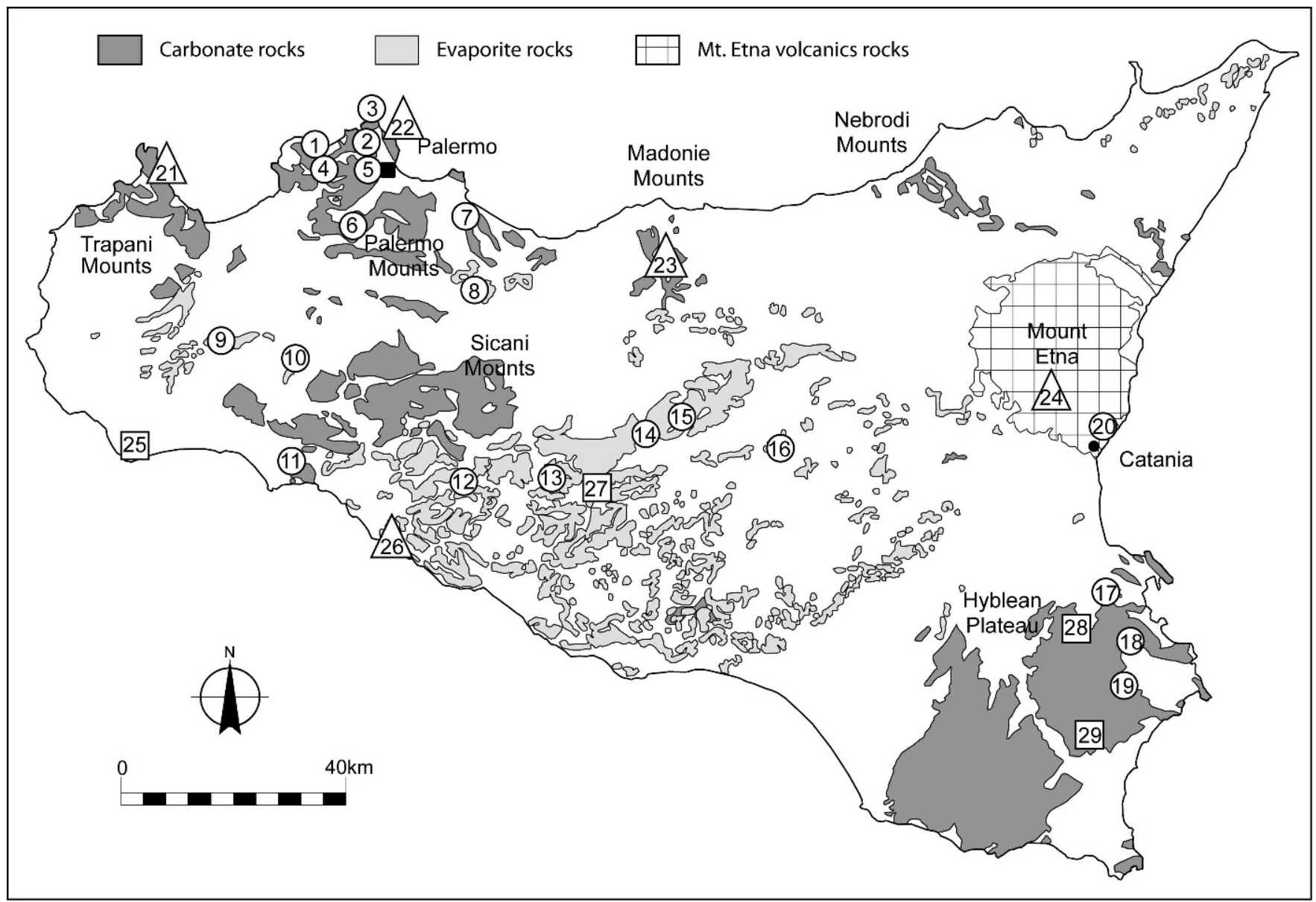

Figure 8. Location map of carbonate and evaporite rocks and natural protected karst areas of Sicily (modified after Catalano, 1986, and Macaluso et al., 2001). Numbers correspond to the list in Table 1. Although volcanic caves are not karst features in the strict sense, they are included in this list. Circles indicate karst areas designated as nature reserves for their intrinsic karst value; squares indicate important karst areas designated as nature reserves for the protection of other environmental heritages; and triangles indicate important karst features developed within regional parks or nature reserves established for the conservation of other environmental features.

subterranean fauna. Besides carbonate and gypsum subsurface cavities, a complex of eight volcanic caves at Mount Etna was declared a nature reserve for the conservation of lava tubes.

Two protected areas were designed to conserve gypsum karst lakes of interest from the geological, hydrological, and biological point of view. Other reserves preserve karst landscapes such as gypsum karren fields, dolines, and swallow holes. In some cases, such as numbers 6 and 7 in Table 1, the protected areas include both karst and important biological features.

Many of these areas contain special habitats of interest and species of biogeographic and preservation importance and have therefore been included in Sites of Community Importance under the Council Directive 92/43/EEC on the conservation of natural habitats and wild fauna and flora or as Special Protection Areas designated in accordance with the Council Directive on the conservation of wild birds, 79/409/EEC. Moreover, there are important karst areas and volcanic caves that are found within regional parks (e.g., the Madonie Geopark includes the carbonate karst of the Madonie Mountains) or nature reserves designated for the conservation of other environmental heritages. For example, several significant caves are located in the nature reserve of Monte Pellegrino (Palermo), which was established for the conservation of its rupestral features and the protection of some bird species. An important karstland in gypsum, marked by karren, dolines and a polje, is encompassed in the nature reserve Torre Salsa in Agrigento province, designated for its environmental and biological interest. At the same time, there are significant protected karst areas that were not established because of their intrinsic value as karst features but for different reasons. Among these, some gypsum karst lakes were designated as nature reserves only for their biological resources and because they represent important staging 
points for many migratory birds, while fluvio-karst canyons were declared nature reserves for the presence of significant associations of flora and fauna.

Most of the protected karst areas are listed as Integral Nature Reserves (INR in Table 1). Each reserve is divided into two areas, Zone A and Zone B, with different land use and protection rules relating to the environmental features and management goals (Casamento et al., 2004). Zone A is the area of maximum protection, where only scientific studies are authorized and tourist access is subject to more restrictive rules. Zone $\mathrm{B}$ is a buffer zone between the maximally protected area and the surrounding territory. In this area, appropriate actions to promote the enhancement of the local economy are permitted, with special focus on traditional, zootechnical, and farming or forestry activities, as well as recreation, tourism, and sports. For example, in the reserves established for cave protection, Zone A includes the cave and a $5 \mathrm{~m}$ radius area around its entrance, while Zone B surrounds Zone A, though generally covering only part of the catchment area of the cave.

Eleven protected karst areas are designated as Oriented Nature Reserves (ONR) and one area is a Special Nature Reserve (SNR). These are also divided into Zone A and Zone $\mathrm{B}$, but the maximum protection area rules are less restrictive than described above.

Management of the nature reserves was assigned by the Sicilian Regional Government to environmental associations such as the World Wildlife Fund, the Italian Alpine Club, and Legambiente or to universities, provincial administrations, or the Dipartimento Regionale Azienda Foreste Demaniali (Regional Forest Department) of Sicily. Their overall goals are to work for the protection and improvement of the natural resources, promote scientific research, and disseminate knowledge of the natural heritages of the reserves. For many protected areas, however, the strategic aim is the integration of the need to protect unique karst landscapes and their natural heritages with the promotion of forms of sustainable development (Dimarca, 2004).

Each nature reserve should have a specific management plan for the karst features and regulations about prohibited and allowed activities in relation to the resources to be protected. But these areas are protected under general environmental legislation, because specific laws for protection of karst are lacking.

Protection and conservation measures are carried out to minimize human pressure on karst. The main threats and issues are infilling of swallow holes and dolines, inappropriate use of fertilizers, unsuitable agricultural and zootechnical practices, grazing, quarrying, wildfires, building of rural homes, waste dumps, dumping of effluent, poaching, water extraction, and unauthorized caving activities. Daily vigilance is maintained in the reserves and the surrounding areas to reduce threats and address illegal activities. Some management staff cooperate with landowners in the protected areas to promote agricultural practices in compliance with sound karst conservation.

To avoid inappropriate speleological activities, access to the caves is possible only after authorization and under the guidance of management staff. In some cases, visitation is controlled to minimize disturbance of the environmental conditions and to protect subterranean fauna.

Restoration of degraded or abandoned areas is carried out to conserve and enhance karst areas. In some reserves, illegally-built structures were demolished, native shrubs and trees species were planted, and degraded zones were changed into areas with native vegetation, educational information, and park amenities.

Scientific research is one of the most important objectives in the nature reserves, as it increases understanding of their values and provides the information needed to preserve them. Interdisciplinary investigations are carried out in close collaboration with universities, research institutes, and freelance researchers. Many students in these areas conduct studies for the preparation of graduation theses, doctoral dissertations, or they perform training activities as part of degree courses. In some reserves, geological, geomorphological, and hydrogeological studies are carried out to increase understanding of the surface and underground karst (Favara et al., 2001; Macaluso et al., 2001; Frisia et al. 2006; Vattano, 2008; G. Madonia and Vattano, 2011). Biological studies have documented the wildlife and vegetation features, creating the conditions for their inclusion in Sites of Community Importance and Special Protection Areas (Pasta and La Mantia, 2001). In the caves, climate monitoring programs are carried out both to increase knowledge and to devise visitor policies (P. Madonia, 2001a, 2001b, 2008). Studies on subterranean fauna documented new species and contributed to the safeguard of the underground habitat.

Much publicity about protected karst areas is advanced in order to create a conscious environmental awareness: participation in exhibitions, conferences, and local and regional trade shows; publication of brochures, calendars, hiking maps, and multi-languages DVDs; and development of environmental education programs that focus on local communities and students of all ages, from primary school to university. Some reserves diligently promote ecotourism and development based on conservation and enhancement of the natural resources, perpetuation of traditional activities, maintenance of cultural identities, and improvement of the local economy. For these purposes, networks of trails and interpretive visitor centers were constructed, some in renovated old buildings. Management bodies cooperate with institutions and local authorities to develop common cultural initiatives. Local businesses and farmers operating in the reserve areas are engaged to promote rural development and traditional agriculture compatible with the maintenance regime.

At present, the state of conservation of karst areas in Sicily may be considered to be at an acceptable level. 
Nevertheless there are numerous issues and difficulties that should be addressed for effective protection and enhancement of karstlands. One of the main problems is the boundaries of the reserve areas. They are often not adequate to safeguard the karst features; for example, the reserves designated for cave protection frequently do not include the entire catchment. Sometimes the cave extends partially outside the boundaries of the reserve, with obvious risks for its conservation; additional important surface landforms and caves may be located outside the protected area. These problems arise mainly because the delineation of the reserves was done on maps at an inappropriate scale $(1: 25,000)$ for accurate representation of karst features. Further, many important natural resources have become better-known through studies carried out after the establishment of the reserves.

The main stewardship difficulties, however, are linked to lack of special legislation for protection of karst areas and to structural problems in the regional conservation policy. The state of conservation of karst areas frequently depends entirely on the efforts made by the management staffs, and only some reserves have achieved the good results described above. Coordination, planning, and control by the Sicilian Regional Government do not occur (Dimarca, 2004; Casamento, 2004). Policies lack continuity due to frequent changes of administration. Also, bureaucratic procedures are often slow and farraginous, leading to serious problems of management effectiveness.

The financial resources assigned annually by the Sicily Region, amounting to about $€ 50,000$, are clearly insufficient for all management activities. There are no funding sources to develop infrastructure or manage and acquire areas of natural and/or management interest. Most of the activities conducted by the management bodies, such as scientific research, environmental rehabilitation, and construction of footpaths, are carried out within projects funded by the European Union. Measures for the support of traditional activities and for the reorientation of existing ones have not been implemented, causing serious problems for the maintenance of the traditional agricultural landscape and the promotion of rural development (Casamento, 2004).

Unfortunately, a good relationship between conservation activity and local communities is not always achieved. Protected areas were often frequented by hunters, used for inappropriate grazing, or subject to fires. This issue is very complex. In a somewhat simplistic way it can be argued that the conflicts may be linked to several factors. On one hand there are the lack of sensitivity of local populations to the protection of the karst environment and the mistrust of farmers towards new land uses and management. On the other hand, communication by some management bodies is weak, involvement of people and local authorities in management activities is lacking, prohibitions are too rigid in some places, and the needs of the local people are sometimes discounted.

\section{Conclusions}

Karst areas in Sicily represent extraordinary environments in their variety and peculiarity and for the study of various solution forms. Carbonate and gypsum karst exhibit a considerable variety of surface and underground landforms and are important habitats for many vegetal and fauna species. The system of protected karst areas of Sicily is one of the most important in Italy, due to the number of nature reserves, the conservation of bio- and geo-diversity, and the number of institutional authorities and environmental associations involved. Despite this, many karstlands of special scientific and environmental significance are not covered by any conservation measures, resulting in severe risks for their maintenance and preservation.

For a better conservation and enhancement of karst areas, specific legislation taking into account the high complexity and vulnerability of karst systems is needed. Greater political and economic efforts by the responsible authorities are required, and the conservation policy needs unified strategy and planning for all Sicilian karstlands. Adequate funding should be dedicated to the management, research, and sustainable development of these unique landscapes. Management bodies should have greater planning and execution autonomy and limited bureaucratic obstacles. Measures for the support of traditional activities and agricultural practices compatible with karst terrains are needed for acceptance in the local communities. Greater efforts by the management bodies both in stewardship activities and in relationships with the local population are crucially important.

Finally, it should be emphasized the uniqueness of the Sicilian gypsum karst areas, which exhibit unique features in the Mediterranean basin due to the size and thickness of the Messinian evaporite successions and the number and variety of karst landforms. As repeatedly recommended by several scholars and environmental associations, the establishment of a nature-reserve network, or an evaporite geopark, that includes both the protected areas and currently unprotected areas of great scientific and environment significance, is crucial for a comprehensive conservation of evaporite karst in Sicily.

\section{Acknowledgements}

We are grateful to Vincenzo Biancone, Giulia Casamento, Gianluca Chiappa, Rosario Di Pietro, Marco Interlandi, and Enza Messana, staff of some of the Sicilian natural reserves, for their friendly helpfulness and for having provided suggestions and information. We thank V. Culotta for photos in Figure 2a and 2c; Arch. DiSTeM for the photo in 3a; Arch. INR Grotta di Santa Ninfa for the photo in Figure 5b; and U. Sauro for the photo in Figure 5c. We also wish to thank the three anonymous reviewers for their constructive comments. Sincere thanks to Robert Brinkmann, whose suggestions have significantly contributed to the improvement this paper. 


\section{REFERENCES}

Agnesi, V., Macaluso, T., and Pipitone, G., 1986, Fenomeni carsici epigei nelle evaporiti in Sicilia: Le Grotte d'Italia, ser. 4, v. 13, p. 123-161.

Agnesi, V., and Macaluso, T., eds., 1989, I gessi di Santa Ninfa ( Trapani): Studio multidisciplinare di un'area carsica: Memorie dell'Istituto Italiano di Speleologia, ser. 2, v. 3, 202 p.

Agnesi, V., Macaluso, T., Madonia, G., and Panzica La Manna, M., 2003, Sicilia: Memorie dell'Istituto Italiano di Speleologia, ser. 2, v. 14, p. 253-278.

Aricò, P., and Vattano, M., 2007, Primo contributo sui depositi a terra rossa dell'Abisso del Vento, Isnello (PA), in Atti $2^{\circ}$ Seminario Internazionale di studi sul Carsismo negli Iblei e nell'area sud Mediterranea, Ragusa, 28-30 maggio 2004: Speleologia Iblea, v. 12, p. $79-84$

Avellone, G., Barchi, M.R., Catalano, R., Gasparo Morticelli, M., and Sulli, A., 2010, Interference between shallow and deep-seated structures in the Sicilian fold and thrust belt, Italy: Journal of the Geological Society [London], v. 167, p. 109-126. doi:10.1144/001676492008-163.

Biancone, V., 1994, Le grotte nel Parco delle Madonie (Sicilia): situazione e prospettive della ricerca speleologica, in Atti del $2^{\circ}$ Congresso Regionale di Speleologia, Catania, 8-11 dicembre 1994: Bollettino dell'Accademia Gioenia di Scienze Naturali, v. 27, no. 348, p. 563-577.

Biancone, V., Messana, E., and Panzica La Manna, M., 1994, Carsismo ipogeo in arre gessose nei pressi di Agrigento (Sicilia centromeridionale), in Atti del $2^{\circ}$ Congresso Regionale di Speleologia, Catania, 8-11 dicembre 1994: Bollettino dell'Accademia Gioenia di Scienze Naturali, v. 27 , no. 348 , p. 477-506.

Buscaglia, G., Interlandi, M.M., and Vattano, M., 2010, Geomorphology and speleogenesis of the Vallone Ponte-Grotte d'Acqua karst system (Sant'Angelo Muxaro - southern Sicily), in $3^{\text {rd }}$ International Symposium on Karst Evolution in the South Mediterranean Area, Ragusa, May 29-31, 2009: Speleologia Iblea, v. 14, p. 161-172.

Calaforra, J.M., and Pulido-Bosch, A., 1999, Genesis and evolution of gypsum tumuli: Earth Surface Processes and Landforms, v. 24, p. 919-930. doi:10.1002/(SICI)1096-9837(199909) 24:10<919::AID-ESP20>3.0.CO; 2-D.

Calaforra, J.M., Forti, P., and Fernandez-Cortes, A., 2008, Speleothems in gypsum caves and their paleoclimatological significance: Environmental Geology, v. 53, no. 5, p. 1099-1105. doi:10.1007/s00254-0070737-3.

Casamento, G., 2004, Bilancio dell'esperienza di Legambiente nella gestione delle Riserve Siciliane: Il Naturalista Siciliano, ser. 4, v. 28, no. 1, p. $769-777$.

Casamento, G., Dimarca, A., Mento, G., and Messana, V., 2004, La tutela delle aree carsiche gessose in Sicilia: status e prospettiva: Memorie dell'Istituto Italiano di Speleologia, ser. 2, v. 16, p. 115-124.

Catalano, R., 1986, Le evaporiti messiniane. Loro ruolo nell'evoluzione geologica della Sicilia: Le Grotte d'Italia, ser. 4, v. 13, p. 109-122.

Catalano, R., Di Stefano, P., Sulli, A., and Vitale, F.P., 1996, Paleogeography and structure of the central Mediterranean: Sicily and its offshore area: Tectonophysics, v. 260, p. 291-323. doi:10.1016/ 0040-1951(95)00196-4.

Catalano, R., Franchino, A., Merlini, S., and Sulli, A., 2000, Central western Sicily structural setting interpreted from seismic reflection profiles: Memorie della Società Geologica Italiana, v. 55, p. 5-16.

Decima, A., and Wezel, F., 1971, Osservazioni sulle evaporiti Messiniane della Sicilia centro-meridionale: Rivista Mineraria Siciliana, no. 132 139 , p. $172-187$.

Di Maggio, C., Di Trapani, F.P., Madonia, G., Salvo, D., and Vattano, M., 2010, First report on the sinkhole phenomena in the Sicilian evaporites (southern Italy), in Atti, $2^{\circ}$ Workshop internazionale I Sinkholes: Gli sprofondamenti catastrofici nell'ambiente naturale ed in quello antropizzato, Roma, December 2009: Rome, Istituto Superiore per la Protezione e la Ricerca Ambientale, p. 299-313.

Dimarca, A., 2004, Le aree naturali protette in Sicilia: Problematiche e prospettive dopo venti anni dall'emanazione della legge regionale: Il Naturalista Siciliano, ser. 4, v. 28, no. 1, p. 721-737.

Favara, R., Francofonte, S., Grassa, F., Liotta, M., Proietto, F., Riccobono, G., and Valenza, M., 2001, Studio idrogeochimico degli acquiferi presenti nell'area della riserva naturale Grotta di Santa Ninfa: in Casamento, G., ed., Le Riserve Naturali Siciliane Gestite da
Legambiente: Un Contributo alla Conoscenza e alla Tutela, suppl.to Il Naturalista Siciliano, ser. 4, v. 25, p. 237-254.

Ferrarese, F., Macaluso, T., Madonia, G., Palmeri, A., and Sauro, U., 2003, Solution and recrystallisation processes and associated landforms in gypsum outcrops of Sicily: Geomorphology, v. 49, p. 25-43. doi:10.1016/S0169-555X(02)00159-9.

Ford, D.C., and Williams, P., 2007, Karst Hydrogeology and Geomorphology: Chichester, UK, John Wiley and Sons, 562 p.

Forti, P., and Rossi, A., 2003, Il carsismo ipogeo nei gessi italiani: Memorie dell'Istituto Italiano di Speleologia, ser. 2, v. 14, p. 65-87.

Forti, P., and Sauro, U., 1996, The gypsum karst of Italy: International Journal of Speleology, v. 25, no. 3-4, p. 239-250.

Frisia, S., Borsato, A., Mangini, A., Spötl, C., Madonia, G., and Sauro, U., 2006, Holocene climate variability in Sicily from a discontinuous stalagmite record and the Mesolithic to Neolithic transition: Quaternary Research, v. 66, no. 3, p. 388-400. doi:10.1016/j.yqres.2006.05.003.

Gemmellaro, M., 1915, Le doline della formazione gessosa a N.-E. di Santaninfa (Trapani): Giornale di Scienze naturali ed economiche, Palermo, v. 31, p. 1-49.

Hill, C., and Forti, P., 1997, Cave minerals of the World: Huntsville, Alabama, National Speleological Society, $464 \mathrm{p}$.

Hugonie, G., 1979, L'évolution géomorphologique de la Sicilie septentrionale [Ph.D. thesis]: Lille, Université Paris IV, 950 p.

Klimchouk, A., 1996, The dissolution and conversion of gypsum and anhydrite: International Journal of Speleology, v. 25, no. 3-4, p. 21-36.

Macaluso, T., Madonia, G., Palmeri, A., and Sauro, U., 2001, Atlante dei karren nelle evaporiti della Sicilia, Quaderni del Museo Geologico "G.G. Gemmellaro", v. 5, Dipartimento di Geologia e Geodesia, Università di Palermo, $143 \mathrm{p}$.

Macaluso, T., Madonia, P., and Panzica La Manna, M., 1994, Tutela e valorizzazione dell'ambiente carsico delle Madonie (Sicilia), in Atti del $2^{\circ}$ Congresso Regionale di Speleologia, Catania, 8-11 dicembre 1994: Bollettino dell'Accademia Gioenia di Scienze Naturali, v. 27, no. 348, p. 641-673.

Macaluso, T., Madonia, G., and Sauro, U., 2003, Le forme di soluzione nei gessi: Memorie dell'Istituto Italiano di Speleologia, ser. 2, v. 14, p. 55-64.

Macaluso, T., and Sauro, U., 1996a, The Karren in evaporite rocks: a proposal of classification: in Fornós, J.J., and Ginés, A., eds., Karren landforms: Palma, Universitat de les Illes Balears, p. 277-293.

Macaluso, T., and Sauro, U., 1996b, Weathering crust and Karren on exposed gypsum surfaces: International Journal of Speleology, v. 25, no. $3-4$, p. $115-126$.

Macaluso, T., and Sauro, U., 1998, Aspects of weathering and landforms evolution on gypsum slopes and ridges of Sicily: Supplements of Geografia Fisica e Dinamica Quaternaria, ser. 4, v. 3, p. 91-99.

Madonia, G., and Sauro, U., 2009, The karren landscapes in the evaporitic rocks of Sicily: in Gines, A., Knez, M., Slabe, T., and Dreybrodt, W., eds., Karst rock features: Karren sculpturing: Ljubljana, ZRC Publishing, Karst Research Institute ZRC SAZU, Postojna, Carsologica, v. 9, p. 525-533.

Madonia, G., and Vattano, M., 2010, Caves in the Belmonte Mezzagno area (North-West Sicily), in Proceedings, $3^{\text {rd }}$ International Symposium on Karst Evolution in the South Mediterranean Area, Ragusa, May 29-31, 2009, Speleologia Iblea, v. 14, p. 143-154.

Madonia, G., and Vattano, M., 2011, New knowledge on the Monte Conca gypsum karst system (central-western Sicily, Italy): Acta Carsologica, v. 40, no. 1, p. 53-64.

Madonia, P., 2001a, Considerazioni preliminari sul monitoraggio di temperatura, umidità e concentrazione di $\mathrm{CO}_{2}$ nell'atmosfera ipogea della Grotta di Santa Ninfa: in Casamento, G., ed., Le Riserve Naturali Siciliane Gestite da Legambiente: Un Contributo alla Conoscenza e alla Tutela, suppl.to Il Naturalista Siciliano, ser. 4, v. 25 , p. $255-269$.

Madonia, P., 2001b, Considerazioni preliminari sul monitoraggio di temperatura, umidità e concentrazione di $\mathrm{CO}_{2}$ nell'atmosfera ipogea della Grotta di Carburangeli: in Casamento, G., ed., Le Riserve Naturali Siciliane Gestite da Legambiente: Un Contributo alla Conoscenza e alla Tutela, suppl.to Il Naturalista Siciliano, ser. 4, v. 25 , p. $379-394$.

Madonia, P., 2008, Monitoring climatic changes and carbon cycle in canyon and caves: the C6 project, in Proceedings, 1st WSEAS International Conference on Environmental and Geological Science and Engineering (EG'08), Malta, September 11-13, 2008, p. 135-142. 
Madonia, P., Panzica La Manna, M., and Vivoli, P., 1983, Attuali conoscenze sul fenomeno carsico della provincia di Palermo: Le Grotte d'Italia, ser. 4, v. 11, p. 183-194.

Mannino, G., 1986, Le grotte del palermitano, Quaderni del Museo Geologico "G.G. Gemmellaro", v. 2, Dipartimento di Geologia e Geodesia, Università di Palermo, $159 \mathrm{p}$.

Marinelli, O., 1896, Alcune notizie sopra il Lago di Pergusa in Sicilia: Rivista Geografica Italiana, v. 3, p. 509-519.

Marinelli, O., 1911, Per lo studio delle grotte e dei fenomeni carsici della Sicilia, in Atti $7^{\circ}$ Congr. geogr. It., Palermo, p. 1-21.

Marinelli, O., 1917, Fenomeni carsici nelle regioni gessose d'Italia: Memorie Geografiche di Giotto Dainelli no. 34 (supplement to Rivista Geografica Italiana, v. 9), p. 263-416.

Messana, E., 1994, Il sistema carsico del gruppo montuoso di M. Inici (Castellammare del Golfo, TP), in Atti del $2^{\circ}$ Congresso Regionale di Speleologia, Catania, 8-11 dicembre 1994: Bollettino dell'Accademia Gioenia di Scienze Naturali, v. 27, no. 348, p. 547-562.

Panzica La Manna, M., 1995, Il sistema carsico ipogeo di S. Angelo Muxaro (AG), in Atti del $1^{\circ}$ Convegno Regionale di Speleologia della Sicilia, Ragusa, 14-16 dicembre 1990, v. 1, p. 47-53.

Pasta, S., and La Mantia, T., 2001, Lineamenti della flora e della vegetazione dell'area della Riserva Naturale "Grotta di Santa Ninfa": in Casamento, G., ed., Le Riserve Naturali Siciliane Gestite da Legambiente: Un Contributo alla Conoscenza e alla Tutela, suppl.to Il Naturalista Siciliano, ser. 4, v. 25, p. 271-297.

Perotti, G., 1994, Kronio. - Le stufe di San Calogero e il loro flusso vaporoso, in Atti del $2^{\circ}$ Congresso Regionale di Speleologia, Catania, 8-11 dicembre 1994: Bollettino dell'Accademia Gioenia di Scienze Naturali, v. 27, no. 348, p. 435-475.
Ruggieri, R., 2002, Peculiarità geomorfologiche e speleologiche dell'area carsica di Custonaci (TP), in Atti del $4^{\circ}$ Convegno di Speleologia della Sicilia, Custonaci, 1-5 maggio 2002: Speleologia Iblea, v. 10, p. 197-203.

Ruggieri, R., and Grasso, M., 2000, Caratteristiche stratigrafiche e strutturali dell'altopiano ragusano e sue implicazioni sulla morfogenesi carsica, in Atti del $1^{\circ}$ Seminario di studi su Il carsismo negli Iblei e nell'area sud mediterranea, Ragusa, 9-11 aprile 1999: Speleologia Iblea, v. 8, p. 19-35.

Sauro, U., 1996, Geomorphological aspects of gypsum karst areas with special emphasis on exposed karst: International Journal of Speleology, v. 25 , no. $3-4$, p. $105-114$.

Sauro, U., 2003a, Aspetti evolutivi del paesaggio carsico nei gessi in Italia: Memorie dell'Istituto Italiano di Speleologia, ser. 2, v. 14, p. 41-45.

Sauro, U., 2003b, Dolines and sinkholes: aspects of evolution and problems of classification: Acta Carsologica, v. 32, no. 2, p. 41-52.

Sauro, U., 2005, Closed depressions: in Culver, D.C., and White, W.B., eds., Encyclopedia of Caves: San Diego, Elsevier/Academic press, p. $108-122$.

Vattano, M., 2004, Geomorphological aspects of Monte Conca Karst system (Caltanissetta, Sicily): Memorie dell'Istituto Italiano di Speleologia, ser. 2, v. 16, p. 103-114.

Vattano, M., 2008, Geomorphological evolution of evaporite karst areas in south-central Sicily by relationship analysis between hypogean karst landforms and surface landforms [Ph.D. thesis]: Palermo, University of Palermo, $250 \mathrm{p}$.

Vattano, M., 2010, The "Paleorisorgenza" of the Monte Conca gypsum karst system (south-central Sicily), in Proceedings, $3^{\text {rd }}$ International Symposium on Karst Evolution in the South Mediterranean Area, Ragusa, May 29-31, 2009: Speleologia Iblea, v. 14, p. 137-141. 